\title{
Case study on sexual and reproductive health and education: reflections on interlinkage and governance
}

\author{
Susannah H. Mayhew ${ }^{*}$, Elaine Unterhalter ${ }^{\dagger}$, \\ Nigel Poole ${ }^{\ddagger}$, Niheer Dasandi ${ }^{\S}$, Niall Winters \\ and on behalf of the Health and Education \\ Cluster, UCL-LIDC: Thinking Beyond Sectors for \\ Sustainable Development
}

${ }^{\star}$ London School of Hygiene and Tropical Medicine, Department of Global Health and Development, ${ }^{~}$ University College London Institute of Education, Department of Humanities and Social Sciences, ${ }^{\star}$ School of Oriental and African Studies, Centre for Environment, Development and Policy, ${ }^{5}$ University College London, School of Public Policy, 'University of Oxford, Department of Education

\section{Introduction}

In this chapter, we select several SDGs on health (SDG 3), education (SDG 4), and gender (SDG 5), and explore their interactions and the challenges this poses for their governance. In the previous chapter, we proposed that these specific goals shared, with some others, a focus on individual and population well-being, and are supported in this by goals which provide the infrastructure and services (e.g. food, energy, and employment) to achieve this, and ultimately by other goals which provide the environmental resources necessary to infrastructure

\section{How to cite this book chapter:}

Mayhew, S. H, Unterhalter, E, Poole, N, Dasandi, N, and Winters, N. 2015.

Case study on sexual and reproductive health and education: reflections on interlinkage and governance. In: Waage, J and Yap, C. (eds.) Thinking Beyond Sectors for Sustainable Development. Pp. 89-107. London: Ubiquity Press. DOI: http:// dx.doi.org/10.5334/bao.i 
and services. We also suggested that, as well-being goals, they have similarities in their governance and institutional structure relating to the historical role of the state in the provision of health and education, and the experience of past international initiatives, particularly the MDGs.

However, we observed that such similarities do not mean that the important links between these goals are easily recognised or governed. In this chapter, we will first present the evidence for important interactions between these goals, and then explore the barriers to their integration, and particularly the problems for governance. Finally, we will explore a number of possible models for governing these interactions.

The reader may want to refer back to chapters in the first part of this book on human health, population growth, and education, information and knowledge, for an insight into the evolution of these different sectors and their goalsetting processes, and to the previous chapter for the conceptual framework on the interactions and governance of the SDGs mentioned above. Finally, while we examine here a specific interaction between only three goals, we seek to illustrate the more general challenges and opportunities for the governance of SDGs and their interactions.

There are many important interactions between interventions in health, education, and gender, but we have selected a particularly significant one for our examination here, the relationship between SRH and education, particularly of young women.

\section{Interactions between sexual and reproductive health and education and their governance challenges}

The interactions between SRH and education are associated both with an interconnection of effects and with processes, intrinsic to each, where the one draws on the other. Demographic and Health Surveys data in many countries show correlation between the uptake of primary education (as measured by enrolment, attendance, and completion) and uptake of SRH services, leading to better outcomes, particularly reduced maternal mortality, better neonatal survival, better sexual health outcomes, greater women's autonomy over decision-making regarding health, and possibly household economics and family redistribution of esteem and influence for women. Thus, through this connection with sexual and reproductive health, we can see a link between girls' schooling and some gender and women's rights goals, as articulated in the Beijing Declaration, the MDGs, and other similar international declarations and agreements.

In trying to understand the interaction between SRH and primary education, we think it is useful to separate out effects as follows: first, that part of the interaction that is noted through impact evaluations; and second, the part of the interaction that is associated with processes, which needs some further 
investigation (the research base on this is not yet so strong). It appears that processes that facilitate the interaction include flows of information and resources, actions of inclusion, and the conferring of esteem. Thus it may be that even being in a position to attend and remain at school, whether or not one formally gains a qualification, or the capacity to read information leaflets, e.g. on contraception, bestows status in a society/community, which is in itself important in securing SRH outcomes.

There are some important gaps in our knowledge: we do not know whether the content of the education, the pedagogy, and how it is organised, have any bearing on SRH outcomes. It appears that generic education is important, but this may be because research has not dug deep enough, and we have not yet teased out the features of which aspects of education are important. Although we see the relationship between schooling and improved SRH outcomes across many different country settings and different kinds of locales, we still do not know the causal relationship or what the 'trigger' process is (and whether it lies in the education system or somewhere else). But we do know that the line of travel goes from what happens to a child to what is done as an adult. However, data on effects of lessons regarding SRH given in school on outcomes later in life are very inconclusive, and much of this research has been conducted specifically in response to the HIV epidemic in sub-Saharan Africa (e.g. Doyle et al. 2010).

Governance concerns show some of the dynamics of school-linked solutions to resistance to classroom teaching on SRH. In most countries there is largescale public sector provision for schooling, although private sector provision is increasing in significance, and there is some public-private partnership; however this will always be a junior partner to public sector provision. By contrast maternal health provision is a mix of public and private sector provision. It is largely private in Asia, there is an emerging private (for-profit) sector in Africa, and some NGO (not-for-profit, including Church-based) provision. In virtually all countries, neonatal health and family planning fall largely into the realm of state provision, unless women deliver in a private health facility. Child immunisation and welfare are generally distributed through the public sector worldwide. Family planning, while also widespread in the public sector, is increasingly distributed through pharmacies (condoms, pills, and emergency contraception). Intrauterine devices, implants, and sterilisation are provided in clinics (mostly public and NGO). Social marketing (subsidised provision, usually through pharmacies) is also important for the distribution of family planning, representing public endorsement for private delivery. This sketch indicates that the big picture framing the interactions between these two fields is largely about public governance, provision and regulation of schooling, and child immunisation and welfare, which branches or morphs into a mix of public-private engagement around SRH for adults (there are some parallels with a wider provision of education for adults). 
International Human Rights agreements, governing actions of both public and private actors, help to frame interactions between these sectors. The International Convention on the Rights of the Child (entered into force in 1990 after global ratification) protects the child's right to the highest attainable standard of health and to education. Protection of SRHR is more difficult, frequently being seen as a socially or culturally defined right, but the declarations and platforms of action from both the 1994 ICPD and 1995 United Nations Conference on Women in Beijing, explicitly link SRH rights to existing human rights detailed under the International Covenant on Economic, Social and Cultural Rights (entered into force 1976). Rights frameworks tend to govern much NGO and public sector work, but the growth of the private sectors in both health and education has created something of a social market, where rights are framed increasingly as 'consumer choices'.

The regulation of the private, for-profit sector in health is very difficult. The relationship of the private for-profit sector with governments is unclear, although governments (States Parties) ultimately have responsibility under international human rights frameworks for the actions of private sector actors under their jurisdiction. Private professional groups (e.g. medical associations) can be very powerful when it comes to influencing policy decisions on health issues: big pharmaceutical companies are extremely powerful lobbyists on policy decision-making, particularly where their interests (e.g. on drugs procurement or licensing) are at stake.

We see something similar in education, where the NGO sector is more in conversation with the public sector, while the private for-profit sector is more autonomous or connects through financial flows and the power of edubusiness (i.e. multinational companies like Pearson PLC which make profits out of selling key components of the education system like the software for conducting standardised tests, textbooks, and so forth). This profit motive is particularly evident in the areas of electronic-based education (elearning), and increasingly in mobile and electronic health (mHealth/eHealth). Often the approach is to highlight problems with educational systems and teachers' practices, and to frame this as a 'crisis' that can be used primarily by the corporate sector as a key rationale to develop parallel and costly systems. These systems are underpinned by the latest technologies (often mobile technologies). While technical innovation is welcome, in many cases is it not adequately supported by real efforts to understand and address the weaknesses identified in educational systems. The crisis thus becomes self-perpetuating: teachers' professional practice comes under continuous questioning, and the weakness of educational systems is highlighted over and over again. However, if education is to be a priority, any proposed technology-based interventions must be seen to work with existing systems in an equitable manner, and seek to improve educational opportunity for all, especially those at the margins of society.

Governance of the NGO sector is somewhat easier, since NGOs often have a commitment to working with governments. They play an important role in 
helping communities to engage with, and accept SRH education through both the education and health sectors. They have often been important in supporting schools to take forward SRH initiatives through girls' clubs, for example, and specialist training for teachers. One particularly successful example, the multidonor funded flagship Geração Biz programme in Mozambique (see Box 1),

Box. 1 Experience of a multi-agency Adolescent SRHR programme in Mozambique

The programme is implemented by an international NGO in collaboration with three ministries: Health, Education and Gender/Youth and Sport and support from UNFPA. The Scandinavian countries and Holland support the programme and plans for going to scale are developed. The International NGOs Pathfinder and IPPF are involved in the training.

The PGB (Programa Geração Biz) started in 1999 as a multi-sectoral/multicomponent pilot project implemented in two provinces. The PGB was gradually scaled up to cover 11 provinces and more than 80 per cent of the districts. From the pilot phase in 1999 up to 2004, the objective of PGB was 'To improve ASRH, increase gender awareness, reduce the incidence of unplanned pregnancies, and decrease young people's vulnerability to STIs, HIV, and unsafe abortion. From 2004, a rights-based approach was adopted and youth participation enhanced. A new objective, expected results, and guiding principles were developed. The objective of the PGB from 2005 to the present is 'To improve ASRH, including a reduction in the incidence of early or unwanted pregnancy, STIs and HIV, through activities that equip young people with the knowledge, skills, and services needed for positive behaviour change' (Country Study Report 2014).

PGB is structured around three main and interlinked components:

i) Youth-friendly clinical services under the responsibility the School and Adolescent Health Section of the Ministry of Health;

ii) In school interventions coordinated by the Department of Special Programmes of the Ministry of Education and implemented by schools; and

iii) Community outreach targeting out-of-school youths coordinated by the National Directorate of Youth of the Ministry of Youth and Sports, and implemented by youth associations.

A 2004 evaluation was positive and recommended that the programme should scale up to cover the whole of Mozambique. Around 2010 donors took the decision to pull out. Adequate alternatives to donor funding were not secured and host-ministry capacities were low, so the programme had largely collapsed by 2014 . 
involved collaboration between NGO and public sectors, including the Ministries of Health, Education, and Youth and Sports, to support community youth groups, develop teaching and information materials, train school teachers in facilitating SRHR knowledge to schoolchildren, and train/equip health staff to meet young people's needs for SRHR services. Lack of sustainable funding proved its downfall.

Over and above some of the dynamics of governance, the history of the link between international goals in education and SRH is important, and has a bearing on how we can understand the interactions. Historically, since the 1960s the promotion of the education of girls and women was associated with initiatives in what was then termed 'family planning'. Later this came to be displaced by increased focus on economics, citizenship, or gender equality. There are institutional links between UNFPA, UNICEF, and UNESCO, as part of the United Nations 'family', but there are also rivalries and the governance structures of these organisations affects how they frame issues; for example, UNESCO is governed by country representation, like the United Nations, while UNICEF accepts private donations, and has been adept at establishing particular kinds of niches. UNFPA was formerly a programme under the UNDP and remains co-located in many countries; like UNESCO it is governed by United Nations member states (12 donors and 24 programme countries). Compared to UNICEF, it has a tiny budget (mostly funded by donor states), and therefore cannot implement programmes; there is sometimes tension between the two over maternal health mandates, though family planning remains the preserve of UNFPA.

The framing of the MDGs, and some of the direction taken by the EFA movement have been associated with something short of trade-offs, more like stumbles, which have made realising the links with SRH more difficult; notably a lack of attention to safety in schools, particularly SRGBV, inadequate opportunities for women's literacy, and access to lifelong learning, which would entail, for example, knowing a mainstream language or being able to attend some kind of discussion group. These gaps have negative consequences for SRH. Moreover, many of the ways in which EFA has been addressed has promoted a human capital approach to education, rather than one with a strong social justice ethos. Thus, currently there is a keen interest in how technology can be used in education to prepare populations for the 'knowledge economy', and in particular, how solutions can be aligned to business needs and the development of life skills. However, in working with marginalised communities there will be a greater need for 'social arrangements that permit all to participate as peers in social life. Overcoming injustice means dismantling institutionalised obstacles that prevent some people from participating on a par with others as full partners in social interaction' (Fraser 2008: 16, cited in Tikly \& Barrett, 2011: 6). According to Tikly (2011), Fraser's work is very significant in that she draws attention to 'three dimensions of social justice' (Tikly \& Barrett, 2011: 6), which we reframe 
here to investigate the role of technology in relation to both education and health:

- Redistribution: Does everyone have access to technology?

- Recognition: Understanding the processes underpinning the marginalisation of particular social excluded groups (e.g. rural girls, nomadic communities, refugees, and indigenous groups). Does the development of new technologies have unintended consequences that could result in continuing to support marginalisation, even indirectly?

- Participation: How can marginalised groups have a voice in any decisionmaking processes that affect their lives? What is the role of technology in supporting this process? How can marginalised groups have a role in the design/rollout of new technologies?

The 2nd June 2013 draft outline of the Open Working Group for Sustainable Development Goals explicitly drew a connection between SRH and education that had been disconnected in previous policy frameworks in their framing of Goals 3, 4, and 5. However, the dominant attention to the interactions in terms of effects, rather than processes, means that the ways to realise these connections are not well understood, and the institutional, organisational, and research undergirding needs to be put in place. The highly politicised nature of SRH was underscored in the negotiations culminating in Revision 1 of the Zero Draft, which saw the removal of the sub-goal for universal access to SRHR from the health Goal and qualified under the gender Goal; a significantly weaker position that risks governments being able to ignore the more difficult SRH issues, such as safe abortion, adolescent contraception, and so forth, because they are no longer a target for the health goal, nor are they seen as a core remit for the gender goal. This was the subject of intense negotiation, with SRHR NGOs lobbying all sympathetic European delegations as well as African and Asian governments, to get them to call for the reinstatement of universal SRHR under the health goal in the final round (13th Session) of the Open Working Group negotiations in July. Universal access to SRHR was successfully reinstated under the health Goal, but it remains to be seen whether it will be retained in the final document to be agreed by the States Parties in June 2015.

\section{Analysing the challenges to governing the interactions}

Power - One way to think about governing interactions links with the public/ private melange in education and SRH discussed above. Education is dominated by the public sector because of a strong association with the legitimation of existing regimes (as schooling is often a key issue in elections, both national and local), publicity around politicians, the formulation of a national identity, 
perceptions about economic achievement, and so forth. As a sector, education is very visible and associated with particular forms of accountability, symbols, and ideas about appropriate distribution. SRH can also be highly political, as noted earlier, but the pathways associated with this tend to be more moral and religious (e.g. on issues such as access to safe abortion, adolescent contraception, and rights for sexual minorities). Although these are highly politicised, they are not so much seen as issues of accountability or drivers of narratives of economic progress. They are unlikely to be linked to charges of corruption or views on how governments construct budgets, but are invoked around symbolic, national, or religious identities which can be very powerful, as well as arguments of gender-equity and the status of women, which have importance for certain types of foreign aid. Maternal and neonatal mortalities tend not to be election issues.

A second way to think about power is to consider individual power. In SRH discussions, women's autonomy is seen as a means and an end, and this is also a feature of the policy discussions in education. Which part of this continuum is stressed tends to be associated with the position of who is talking. Some of the conceptual knitting of ideas, empowerment, and inter-sectionality has been formulated in each sector and then critiqued, but the connection between them has not been much worked up analytically or empirically.

Global framings - initially the population control/sustainability argument drove much discourse on development in the 1950s and 1960s (at this time education was largely about primary provision and adult literacy). In the 1980s in SRH, NGOs and women's rights groups took a different path, culminating in the ICPD in 1994 and the shift from population control to women's sexual and reproductive rights, bodily autonomy, and so forth. In education in the late 1980s, there was a period of struggle between UNESCO, UNICEF, and World Bank over structural adjustment and whether it can have a human face, i.e. big or small state, and what kind of role there can be for the market and the community. This was resolved in 1990 with the EFA movement identifying education needs and rights as the conceptual glue that can hold together quite different framings of what the global landscape is or should be. The MDGs with a goal on maternal health provide a mechanism for NGOs and civil society groups to hold governments to account. This movement does not link up at all with the EFA movement, nor with the ICPD (which delinked population from development). The MDGs focus on UPE separates out the connection with maternal health, and means that different NGO or citizen collations are holding different sections of government or the global machinery to account. The 2000 period is one of parallel initiatives and attempts to start to reconnect, but it is quite fragile, and very much a plaything of the aid fashions and donor power (Mayhew \& Adjei 2004; Unterhalter 2014).

Ideas - In the 1960s, education and population control were both seen as pathways to economic growth. Neither was framed in terms of autonomy, individual rights, citizenship, or inclusion. Today, other than discussions of 
correlation, very few ideas link education and SRH together. Institutionally they are taught in separate schools, handled by different departments, and debated at different conferences. Delinking population and health does not help, but some of the conceptual knitting ideas (empowerment and intersectionality) have begun to take forward connections, however these have stalled. In relation to discussions of population, this is a difficult topic to broach because of historical associations of population discussion with forced sterilisation, coercion, and fears of eugenics (from past policies in India, China, and Nazi Germany). This has made it very difficult to take forward any discussion of population linked to rights, even within the health community (Newman et al. 2014).

In education the way the field of ideas has developed has been through turning inwards to a concern with learning and quality, a focus on pedagogy and management, but not on the links with other sectors, except in broad brushstrokes or taken as obvious givens. For example, there are ubiquitous depictions along the lines of 'if you educate a girl... you solve every development problem' (Monkman \& Hoffman 2013; Unterhalter 2015, in press). The history of the ideas in the field indicate parallel discourses to those in SRH aiming in the same direction (individual rights and women's equity for improved development), but are not very clear on how to get there together, with no exploration of what needs to link up with what/who and why/how?

We thus have two very powerful sectors, which claim to be public goods and to constitute the moral underpinning of all other development goals. Each wants to retain its own territory, bureaucratic machineries, and technologies. In the health sector the power of doctors is notable; in the education sector there is considerable power of the higher education sector and political parties' machineries. In both cases these are groupings with hydraulic influence. In Ghana, for example, there has been a devolution of a lot of social development to local government. But there has been no decentralisation in health and in education this has been uneven (S. H. Mayhew, personal communications 2013). Although there are proposals for decentralisation, there is great resistance to change, and officials at a local level merely carry out decisions taken far away in the capital. In South Africa, where education and hospitals were devolved to provinces as part of the constitutional settlement in 1994, this is seen as raising many difficult issues about management and concerns about efficiency and delivery. In the face of this, application is sometimes made to the private sector to come in and 'make good'.

\section{Critical junctures}

Clearly there are many critical junctures for these two fields, and the SDGs provide an opportunity to both raise awareness of them and move towards realising actions to enhance them. There is an attenuated engagement 
between education, women, and health, but with very few substantive connections around programming, policy, and practice. There is much to do. Forecasting of population and its distribution (migration, urbanisation, and so forth) is not very well done in either the health or education sectors, although it is well used by the private sector wanting to know the nature and location of their future markets. Demographics is not seen as an accountability issue. The women's movement and the education community need to re-engage. The coalition of women's groups and SRH health activists that negotiated the Cairo agreement was not sustained, but could reconnect. In education, the links with the women's movement would need to be built from the beginning.

\section{Potential solutions and their implementation}

As the previous chapter argued, the diversity of the SDGs requires new thinking about governance and mechanisms that transcend existing governance mechanisms. In the concentric circles model presented there, health and education goals fall in the inner circle (individual and collective outcomes). These are well-established components of government policies worldwide and can be naturally synergistic, as the connections between education and SRH outcomes discussed in this chapter serve to illustrate. There are wellestablished governance mechanisms for these goals but, as this chapter has also shown, there are nevertheless many governance challenges; particularly in the context of the promotion of private-sector technologies and extension of market economy principles into what has traditionally been public sector territory, which is changing the public-private mix of the governance landscape.

The conceptual framework introduced in the last chapter also illustrates the interactions between levels of goals: inner- and middle-level (infrastructural) goals are seen as reciprocal, e.g. reliable, resilient infrastructure and energy are necessary to deliver health and education services, while an educated, healthy labour force is necessary for promotion of sustainable economic growth. The outer-level goals (environment and underlying support systems) are seen as the goals underpinning sustainable development, though there are specific interconnections with the inner-level goals. For example, population dynamics (growth, migration, and urbanisation) are influenced by availability and acceptability of contraceptive services, delivered by public and private health infrastructures as well as education (as described in this chapter). Population dynamics also have direct and indirect effects on climate and environmental change. Governance systems need to be able to address such complex interactions. The previous chapter on Governing Sustainable Development Goals argues that interactions between goals at the same level (as between health/SRH and education) are theoretically more governable, and the greatest governance 
challenge (which will have an effect on the achievement of all levels of SDGs) is governance of the middle-level infrastructural goals.

In this final section we explore possible solutions to the complexities facing the governance of SDGs interactions. Stakeholders are key to resolving the governance challenges associated with which targets come under which goals. The final position of the targets under set goals will influence which stakeholders are considered primary actors and who they are likely to interact with. We first consider who the main stakeholders are for governing interactions between health and education sectors under two different final-target scenarios. Both health and education sectors are characterised by strong and independent governance structures that potentially make it hard to govern across them. Second, we therefore explore how institutional silos that currently create barriers to effective, synergistic governance might be broken down.

\section{Stakeholders}

The deletion, in the penultimate draft of the SDGs, of the SRH target from the health goal and its repositioning under the gender goal quite significantly changed the potential and primary stakeholders (see Table 1 below). Although it was reinstated under the health goal in the final draft, ${ }^{10}$ it could still be lost during the year-long intergovernmental discussions that began in November 2014. If it is, the attainment of universal access to SRHR will be under threat, and the contribution of the education sector in helping to attain SRHR goals could become much more significant. Typically, ministries of health would be expected to lead on attainment of the SRHR target, but sensitive elements within it (especially access to safe abortion services, adolescent contraception, and rights of sexual minorities) remain controversial and opposed by many governments. Moving the SRHR target under the gender goal deflects responsibility from the health sector to a much weaker ministry (gender or women's affairs), requiring a much greater effort on the part of dedicated stakeholders and advocates to ensure their efforts are seen as legitimate activities for the health sector targets (which would not include this goal). This will not be a problem in countries whose governments are committed to upholding SRHR rights as defined in Cairo and Beijing, but it will be a significant barrier to effective implementation of SRHR in countries whose governments roundly oppose the full SRHR agenda.

Historically, links between ministries of health and ministries of education are weak (although there are similarities between these two powerful sectors, as noted earlier). It may be that in Scenario 2 in Table 1 there is an opportunity and a need for ministries of education to play a key role

\footnotetext{
${ }^{10}$ As of April 2015.
} 
in helping to achieve the SRHR target, through stepping up its efforts at school-based SRHR education and school-based health care (including contraception). In the long-term, if ministries of education can prioritise attainment of target 4.2 (ensuring all girls and boys complete quality primary education), this would have a significant impact on improving the uptake of contraceptives over a generation, which would itself lead to a significant improvement in the main SRHR goals, providing access to a choice of family planning methods.

\begin{tabular}{|c|c|c|}
\hline & $\begin{array}{c}\text { Scenario 1: Retaining } \\
\text { 'Universal access to SRHR' } \\
\text { within Goal } 4 \text { (Health) }\end{array}$ & $\begin{array}{c}\text { Scenario 2: 'Universal access } \\
\text { to SRHR' appears only in the } \\
\text { Goal } 5 \text { (Gender) }\end{array}$ \\
\hline $\begin{array}{l}\text { Primary } \\
\text { Stakeholders }\end{array}$ & $\begin{array}{l}\text { - Ministries of health } \\
\text { - Public health services (man- } \\
\text { agers, providers) } \\
\text { - NGOs and their service } \\
\text { providers } \\
\text { - Private for-profit providers } \\
\text { - Professional medical associa- } \\
\text { tions }\end{array}$ & $\begin{array}{l}\text { - Ministries of women's affairs/ } \\
\text { gender } \\
\text { - Women's rights NGOs }\end{array}$ \\
\hline $\begin{array}{l}\text { Secondary } \\
\text { Stakeholders }\end{array}$ & $\begin{array}{l}\text { - Ministries of education } \\
\text { - Ministries of youth/sport } \\
\text { - Ministries of women/gender } \\
\text { - UN/IGOs working on } \\
\text { women's health issues in } \\
\text { particular } \\
\text { - Health sector donors } \\
\text { - SRHR advocacy NGOs/CSOs } \\
\text { - Ministries of finance (usually } \\
\text { hold budget lines for com- } \\
\text { modities procurement) }\end{array}$ & $\begin{array}{l}\text { - Ministries of health } \\
\text { - Ministries of education } \\
\text { - Ministries of youth/sport } \\
\text { - UN/IGOs working on women's } \\
\text { health issues in particular } \\
\text { - SRHR advocacy NGOs/CSOs } \\
\text { (may still wish to be involved in } \\
\text { promoting SRHR) } \\
\text { - Health sector donors (may still } \\
\text { wish to be involved in promot- } \\
\text { ing SRHR) }\end{array}$ \\
\hline $\begin{array}{l}\text { Other } \\
\text { Stakeholders }\end{array}$ & - Women's rights NGOs & $\begin{array}{l}\text { - Health service providers } \\
\text { (public, NGO, and private) } \\
\text { will only be seen as stakehold- } \\
\text { ers if target } 5.6 \text { is pursued by } \\
\text { ministries of health (although } \\
\text { some NGOs and possibly } \\
\text { private providers may pursue } \\
\text { elements of the target } \\
\text { unilaterally). } \\
\text { - Ministries of finance (usually } \\
\text { hold budget lines for commodi- } \\
\text { ties procurement) }\end{array}$ \\
\hline
\end{tabular}

(Contd.) 


\begin{tabular}{|l|l|l|}
\hline Risks & $\begin{array}{c}\text { Scenario 1: Retaining } \\
\text { 'Universal access to SRHR' } \\
\text { within Goal 4 (Health) }\end{array}$ & $\begin{array}{l}\text { Scenario 2: 'Universal access } \\
\text { to SRHR' appears only in the } \\
\text { Goal 5 (Gender) }\end{array}$ \\
$\begin{array}{l}\text { Controversial elements (safe } \\
\text { abortion; adolescent family } \\
\text { planning and sexuality educa- } \\
\text { tion; and right to education, } \\
\text { information, and services for } \\
\text { sexual minorities) are down- } \\
\text { played by ministries of health, } \\
\text { but it will be difficult to ignore } \\
\text { them entirely. }\end{array}$ & $\begin{array}{l}\text { Without ministries of health } \\
\text { acting as lead stakeholders it is } \\
\text { much easier for governments } \\
\text { to ignore sensitive SRHR issues } \\
\text { entirely. Ministries of gender/ } \\
\text { women (note how the two are } \\
\text { often used synonymously) are } \\
\text { typically very weak ministries; } \\
\text { there are occasional exceptions, } \\
\text { but it largely depends on leader- } \\
\text { ship and the extent to which that } \\
\text { leadership has the ear of other } \\
\text { powerful ministers/leaders. }\end{array}$ \\
& $\begin{array}{l}\text { Health has not typically been } \\
\text { regarded as a core mandate for } \\
\text { gender and equality actions, so } \\
\text { making a new set of alliances, } \\
\text { including with health, youth, and } \\
\text { education ministries, will take } \\
\text { considerable time and effort. }\end{array}$ \\
\hline
\end{tabular}

Table 1: Key stakeholders for governance of linkages between sexual and reproductive health and education in two Sustainable Development Goals scenarios.

CSO, civil society organisation; IGO, inter-governmental organisation; NGO, non-governmental organisation; SRHR, sexual and reproductive health and rights; UN, United Nations.

Once the final placement of targets is confirmed, it will be clear who the primary stakeholders should be for each goal and target. However, given all the possible multiple interactions between the SGDs, it is unclear who will, or should be tasked with acting on adapting or establishing the structures and mechanisms to govern these interactions.

\section{How can institutional silos be tackled?}

Conducting development work in governmental or institutional silos is nothing new, and in the health sector it has been debated for nearly half a century in terms of whether, at what level, and which programmes should be aligned or integrated to form 'holistic' care versus being provided separately or 'selectively'. There are still no clear criteria for achieving integrated care even for packages of services within the most clearly related areas (e.g. linking HIV and other SRH 
services or the 'integrated management of childhood illnesses') (WHO 2015). Breaking down silos between entire sectors is significantly harder, and requires considerable and sustained effort by strong leaders of the different sectors, particularly where there is no consensus on whose responsibility it should be to oversee progress on sensitive targets.

While resource allocation for inter-sectoral work through budgetary processes in, for example, a ministry of finance or national planning commission will take place at the highest national executive level, assigning responsibility for cross-cutting activities requires coordination at the level of separate national ministries. For example, there are studies from Mozambique of successful interlinkages between ministries at a programme level, where a range of government, NGO, and donor actors have come together within a clearly demarcated and supported governance structure, shared between relevant ministries on a rotating basis, but sustaining those interlinkages without strong leadership and adequate financing is problematic (see Box $\mathbf{1}$ on the Geração Biz programme). A number of characteristics of successful national governance initiatives can also be distilled from political reform literature, notably Grindle's work on education reforms in South America (Grindle 2004):

- Leadership is critical: to appoint/work for or with other leaders who give strategic support, seize windows of opportunity when they arise, marginalise opponents, and frame the issues to gain strategic support (see Box 2 on Indian economic reforms);

Box. 2 Key characteristics of Indian economic reforms in 1980s-90s

The executive leaders set the terms of debates about economic reform in the country. Prime Minister Rajiv Gandhi, under whose leadership the reforms were initiated, was careful to avoid framing the debate along ideological lines. Instead, he emphasised the changing nature of the global economy, and the need for a change in policy so that India would not lag behind other countries.

A key role was played by 'the change team', made up of a group of senior bureaucrats and politicians committed to economic reform in the country. The design team consisted of a number of senior bureaucrats who had developed similar ideas about economic reform from having spent time abroad and having been exposed to new economic ideas. The design team went about trying to broaden support for the reforms within various bureaucracies.

His successor, Prime Minister Chandra Shekhar, publicly took a more critical stance towards proposed economic liberalisation to appease voters, while privately encouraging the reform team to be bolder with their proposals.

Source: Shastri, V. (1997). The politics of economic liberalisation in India. Contemporary South Asia, 6(1), 27-56. 
- Establishment of reform teams (with careful thought to composition and placement) able to get on with the job and protected from political debate (see Box 2 on India), in particular securing safe spaces for debate and planning with a wide range of stakeholders;

- Flexibility of implementation is necessary:

- Developing a 'problem-driven iterative adaptive approach' (Andrews, Pritchett \& Woolcock 2013);

- Devolution and inter-sectoral planning is probably useful for achieving this.

- Inclusiveness of all key stakeholders is important for achieving buy-in and consensus.

However, governing complex links between health and education in the context of the wider SDGs, which have multiple spheres of interaction at multiple levels, must ultimately go well beyond two or three national sectors to account for the connections to the middle-level infrastructural goals, which are hardest to govern but provide the crucial link across all levels of SDGs.

At an aggregate level, a global institutional architecture with national linkages is probably needed for strategy and policy, especially for handling multisectoral goals with synergies, trade-offs, and conflicts, and for monitoring, reporting, and verification of progress. The United Nations agencies provide the most obvious existing global institutional framework, but are fragmented and have struggled to achieve effective cross-sector coordination in the past. Nevertheless, creating new global and national systems and bureaucracies will be unwelcome for many. Appropriate governance can be informed by other existing international collaborations to address specific obligations, targets, or movements in areas other than health and education. These experiences may provide lessons about what does and does not work as governance mechanisms for complex development themes such as the SDGs.

\section{Learning from existing models of inter-sectoral governance}

We draw on a number of models or approaches that could be pursued, or at least their principles can provide lessons, to facilitate the political management and governance required to achieve a balance of political leadership, bureaucratic capacity, and the voice and mobilisation of citizens and civil society to pursue legitimate and accountable goals (see chapter 8).

First, a task force is a grouping of diverse individuals or organisations concerned with a theme of common interest, with clearly defined analytical and executive purposes, and with its key attributes being participation, advocacy, focus, and accountability. Accountability for each goal is likely to be located within and through a particular ministry. Leadership can be through an internal or external appointee made by that ministry. The composition of a taskforce would reflect the range of expert stakeholders, likely drawn from the public 
sector, international organisations, national civil society, and the private sector. One example of a task force approach is that which was used in Zambia in 2007 to analyse and develop opportunities for the acceleration of the commercial utilisation of cassava (Chitundu, Droppelmann \& Haggblade 2006). Processes were not entirely smooth, nor outcomes unproblematic, but the approach to multi-stakeholder problem-solving was valuable and replicable (Poole 2010).

A second model for the governance of multi-sectoral and independent players is the cluster approach used by the humanitarian system to improve capacity, predictability, accountability, leadership, and partnership in the coordination of responses to humanitarian needs: 'Clusters provide a clear point of contact and are accountable for adequate and appropriate humanitarian assistance. Clusters create partnerships between international humanitarian actors, national and local authorities, and civil society' (UN OCHA 2015). In the case of such humanitarian work, it is the United Nations Office for the Coordination of Humanitarian Affairs (UN OCHA) that works closely with global and national cluster lead agencies and NGOs to develop policies, coordinate intercluster issues, disseminate operational guidance, and organise field support. An acknowledged successful case of cluster coordination is the Nutrition Cluster in Afghanistan. Similarly, significant lessons can be learnt from the global Education Cluster set up by Save the Children and UNICEF (UN ALNAP 2015).

A third is the UN-REDD: the United Nations collaborative initiative on reducing emissions from deforestation and forest degradation in developing countries that bears closest relation to proposed Goal 15 (Protect, restore and promote sustainable use of terrestrial ecosystems, sustainably manage forests, combat desertification, and halt and reverse land degradation and halt biodiversity loss, outer circle), and has synergies with at least proposed Goals 1 (End poverty in all forms everywhere, inner circle) and 2 (End hunger, achieve food security and improved nutrition and promote sustainable agriculture: inner and middle circles), and probably proposed Goal 6 (Ensure availability and sustainable management of water and sanitation for all, cross-cuts all three circles). A convening role and technical expertise are provided by three United Nations organisations: the FAO, the UNDP, and the UNEP. Each is a lead agency for one or more of the work areas. The objective of UN-REDD is to support national processes and promote inclusion of all stakeholders, including indigenous peoples and other forest-dependent communities (UN-REDD 2015). Figure 3 gives an example of how UN-REDD partners were configured for governance in Paraguay.

The United Nations are not the only type of apex organisation, nor do all models of global governance necessarily share the same principles of coordination, devolution, and accountability. 'Justice for all' specifically appears in proposed Goal 16, but could be considered to underpin other Goals. An existing institution in this field is the International Criminal Court (ICC) at The Hague in the Netherlands. The ICC was founded on the basis of the Rome Statute, which entered into force on 1 July 2002 after ratification by 60 countries, established to help end impunity for the perpetrators of the most serious crimes of concern to the 


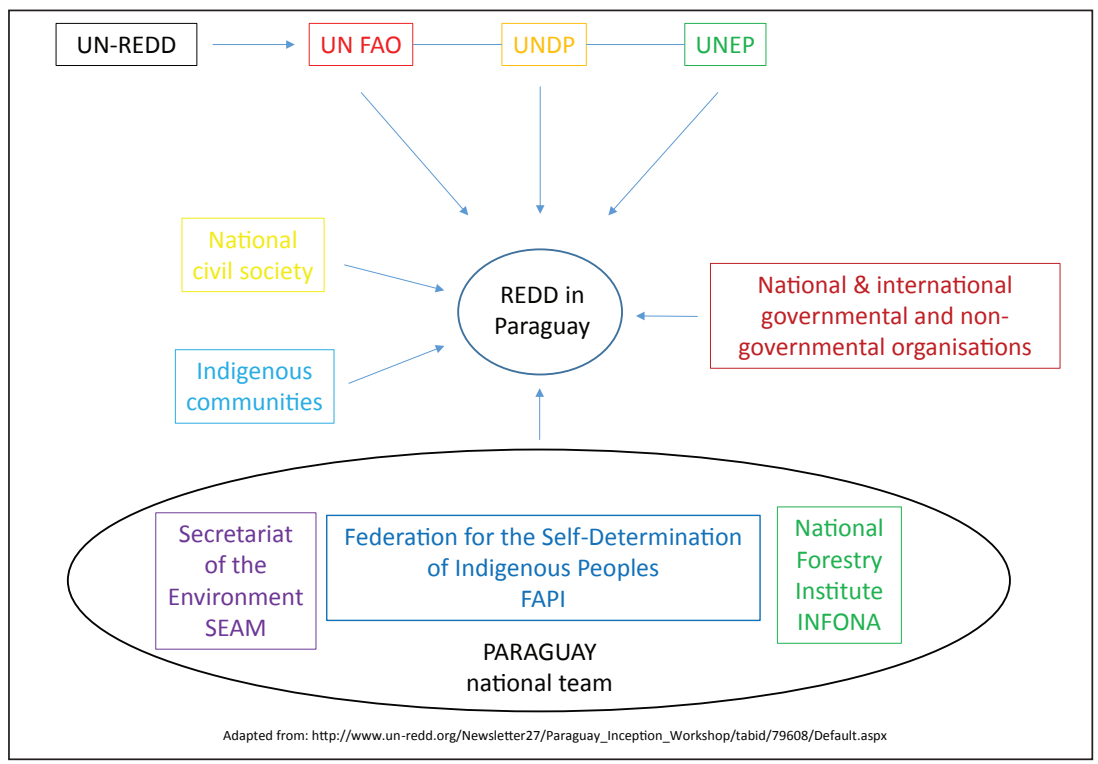

Figure 3: The configuration of the United Nations Collaborative Programme on Reducing Emissions from Deforestation and Forest Degradation partners in Paraguay.

international community (ICC 2015). The ICC is not part of the United Nations system. It is funded primarily by States Parties and also receives voluntary contributions from governments, international organisations, individuals, corporations, and other entities. The limitations in the operation and achievements of the ICC does not invalidate the inter-sectoral and multi-stakeholder model per se. The potential configurations of transnational and multilevel groupings are numerous, and optimal formulations will depend on local circumstances.

\section{Achieving implementation}

The models and essential characteristics noted above all have considerable challenges associated with successful implementation. Key among these (again drawing on political reform literature) are as follows: ensuring how any decision-making or governance body goes beyond a talking shop: many interagency taskforces or multi-sector planning/oversight bodies have failed because of a failure to clearly demarcate responsibilities between the different agencies. There must be transparent accountability of such bodies to build trust and confidence in their decisions and actions. The question of where bodies are based is important, and there can be a big difference between the political face and what happens behind the scenes (see Box 2). 
Overall, the analysis of the challenges of governing the interactions between two inner-circle goals (health, specifically SRH, and education) show that even within inner circle SDGs, there are many complexities facing the development and implementation of successful governance approaches and mechanisms. The complexity increases with the need to additionally govern the interactions between the inner- and middle-level goals (individual and collection outcome, and infrastructure). We have drawn on political science literature and existing examples of multi-sector/multi-agency governance to suggest possible governance models that might be considered by national and international stakeholders responsible for implementing the SDGs. Whilst it is clear that governing the interactions between SDGs will be extremely challenging, it is equally clear that the success of the SDGs, both individually and collectively, will depend on effective cross-sector governance mechanisms being established and implemented.

\section{References}

Andrews, M., Pritchett, L., Woolcock, M. (2013). Escaping capability traps through Problem Driven Iterative Adaptation (PDIA). World Development Vol 51, November 2013. 234-244. DOI: http://dx.doi.org/10.1016/j. worlddev.2013.05.011

Chitundu, M., Droppelmann, K., \& Haggblade, S. (2006). Value chain task force approaches for managing private-public partnerships: Zambia's task for on acceleration of cassava utilisation. Working paper No. 21. Lusaka, Zambia: Food Security Research Project. Retrieved from http://ageconsearch.umn. edu/bitstream/54480/2/wp_21.pdf

Doyle, A. M, Ross, D. A., Maganja, K., Baisley, K., Masesa, C., Andreasen, A., Plummer, M. J., et al. (2010). Long-term biological and behavioural impact of an adolescent sexual health intervention in Tanzania: follow-up survey of the community-based MEMA kwa Vijana Trial. PLoS Med, 7(6), e1000287. DOI: http://dx.doi.org/10.1371/journal.pmed.1000287

Fraser, N. (2008). Scales of justice: reimagining political space in a globalising world. Cambridge: Polity Press.

Freeman T., Matsinhe C., Mayhew S.H. for DANIDA (2014). Evaluation of the Danish strategy for the promotion of sexual and reproductive health and rights 2006-2013: Country Study Report: Mozambique: Ministry of Foreign Affairs: Danida, July 2014.

Grindle, M. S. (2004). Despite the odds: the contentious politics of education reform. Princeton, NJ: Princeton University Press.

International Criminal Court (ICC). (2015). About the court. Retrieved from http://www.icc-cpi.int/en_menus/icc/about\%20the\%20court/Pages/ about $\% 20$ the $\% 20$ court.aspx 
Mayhew S. H., \& Adjei S. (2004). Sexual and reproductive health: challenges for priority setting in Ghana's health reforms. Health Policy and Planning, 19(Suppl. 1), 50-61.

Monkman, K., \& Hoffman, L. (2013). Girls' education: the power of policy discourse. Theory and Research in Education, 11.1(2013), 63-84.

Newman, K., Fisher, S., Mayhew, S., \& Stephenson, J. (2014). Population, sexual and reproductive health, rights and sustainable development: forging a common agenda. Reproductive Health Matters, 22(43), 53-64. DOI: http:// dx.doi.org/10.1016/S0968-8080(14)43770-

Poole, N. D. (2010). Zambia cassava sector policy - recommendations in support of strategy implementation. EU-AAACP Paper Series No. 16. Rome: Food and Agriculture Organization of the United Nations. Retrieved from http://www.euacpcommodities.eu/files/1ESAA01FAO\%20AAACP\%20 Paper\%20Series\%2016\%20Recommendations\%20Zambia\%20Cassava\%20 Strat.pdf

Shastri, V. (1997). The politics of economic liberalisation in India. Contemporary South Asia, 6(1), 27-56.

Tikly, L. \& Barrett, A. (2011) Social justice, capabilities and the quality of education in low income countries, International Journal of Educational Development, 31: 3-14 .

United Nations Active Learning Network for Accountability and Performance in Humanitarian Action (UN ALNAP). (2015). Review of the global education cluster co-leadership arrangement. Retrieved from http://www.alnap. org/resource/6354

United Nations collaborative initiative on Reducing Emissions from Deforestation and forest Degradation in developing countries (UN-REDD). (2015). About the UN-REDD Programme. Retrieved from http://www.un-redd.org/ AboutUN-REDDProgramme/tabid/102613/Default.aspx

United Nations Office for the Coordination of Humanitarian Affairs (UN OCHA). (2015). Cluster coordination. Retrieved from http://www.unocha. org/what-we-do/coordination-tools/cluster-coordination

Unterhalter, E. (2014). Measuring education for the Millennium Development Goals: reflections on targets, indicators, and a post-2015 framework. Journal of Human Development and Capabilities, 15(1-2), 176-187.

Unterhalter, E. (2015). Gender and education in the global polity. In: K. Mundy, A. Green, B. Lingard, \& A. Verger (Eds.), Handbook of global policy and policy making in education. London: Wiley-Blackwell, in press.

World Health Organization (WHO). (2015). Maternal, Newborn, Child and Adolescent Health: Integrated Management of Childhood Illness. Retrieved from http://www.who.int/maternal_child_adolescent/topics/child/imci/en/ 
